\title{
Applying experience of APR countries in field of environmental business to Russian economy
}

\author{
Sipacheva Veronika Yurevna, Oleynik Galina Sergeevna, Bessonova Anastasia Alexeevna, Kachura Ekaterina \\ Pavlovna \\ Finance\&Credit Department \\ Far East Federal University \\ Vladivostok, Russia \\ inverika@mail.ru
}

\begin{abstract}
In spite of the fact that Russia is rather significant country, there is a lack of researches that embrace the role of environmental entrepreneurship as a development of Russian commitment to green economy. In this article, the authors define three models of increasing the number of green companies (taking into account the experience of such countries as China, the U.S., the Republic of Korea and Japan). Furthermore, the authors propose the model of interaction between government and enterprises in conditions of emerging economy. Finally, just three different mechanisms of interaction of governments and businesses were determined.
\end{abstract}

Keywords-ecoprenuring; environmental business; governmental regulation; mechanisms of interaction; Developing Countries

\section{INTRODUCTION}

The majority of people - businessmen, journalists, politicians as well as individual consumers - see green entrepreneurship as a recent phenomenon, something that has suddenly appeared, perhaps due to particular influencers. By now, exploration of relations between the entrepreneurships and environment has not finished, though a theoretical base of this subject was described by a variety of terms. For example, ecoprenuring is defined by Isaak as "system-transforming, socially committed environmental business, characterized by breakthrough innovation" [1]. Another definition is given by Hendrickson and Tuttle; they consider this as 'entrepreneurial activity that benefits the environment' [2].

There was almost ubiquitous pollution in the beginning of 1960s. By the 1980s, a few clever companies figured out that if nobody pollutes the environment in the first place, nobody has to worry about controlling and cleaning up. Thus, the idea of pollution prevention, waste reduction and energy efficiency appeared, and companies started rethinking their processes and management systems to reduce waste and costs

To achieve green economy goals, a huge amount of work must be done at three levels: global, governmental and at the level of local enterprises. Such approach guarantees full coverage of related ecological, social and economic issues [3].

However, different countries have different reasons and methods of moving towards enhanced green entrepreneurship growth. The Republic of Korea adopted a national strategy allocating $2 \%$ of its gross domestic product to investment in several green sectors such as renewable energy, energy efficiency, clean technology and water. China now invests more than any other country in renewable energy [4]. This growth is driven by a national policy, which considers clean energy as a major market in the nearest future, and one in which China wants to reach a competitive edge [5]. After the nuclear disaster in March 2011, national green economy policy starts focusing on development of renewable energy technologies $[6,7]$.

\section{LITERATURE REVIEW}

Researchers in the 1970s and 1980s were mostly concerned with the questions of sustainable development [7]. The so-called "holy grail" at this time was the correlation between man's activity and changes in nature (climate change, growth of desert areas, etc.) [8].

Conceptually, the development of a green economy occurred in two ways. Firstly, the company realized that cleaner technologies can help to increase business efficiency and to attract consumers, which is a competitive advantage [9]. But in most industries implementation of green technologies would be difficult and rather pricy. Moreover, there is no guarantee that consumers will be ready to pay more for "green" products. And here state's government comes into action providing subsidies and aid programs to encourage ecoentrepreneurships.

It is vital to point out that the development of green economy can be accelerated by a systematic supervision. For example, at the local level, government regulates contradictions between green and non-green enterprises giving significant support to the first ones. On a global scale, international organizations can play the same role of a supervisor.

After several decades of environmental research, it is now hard to find a scientist who disagrees with the notion that humans are severely degrading many of the Earth's ecosystems. In addition, even though the debate on just how much human activities affect the environment continues, the business sector is often viewed as one of the largest contributors to environmental degradation [10]. The processes of business units functioning are considered by Smirnov [11, $12,13]$. 


\section{RESEARCH METHODOLOGY}

This research has been done by analyzing the scientific papers, which explored the experience of the ecological entrepreneurship, collected from different countries all over the world. [14]. These sources include information from relevant trade publications, newspapers, magazines, annual reports of United Nations divisions, on-line data bases and other published materials. This information was grouped, explored, and finally, just three mechanisms of ecological entrepreneurship were identified. In order to create the models, the authors analyzed the main vectors of development of ecological business in the US [15], China[16], Japan [17] and in the Republic of Korea [18].

Finally, just three different mechanisms of interaction of governments and businesses were determined.

The prevailing economic growth model is focused on increasing GDP more than on all other goals. While this system has improved incomes and reduced poverty for hundreds of millions, it comes with significant and potentially irreversible social, environmental and economic costs. Poverty persists for as many as two and a half billion people, and the natural wealth of the planet is rapidly being drawn down. In a recent global assessment, approximately 60 percent of the world's ecosystem services were found to be degraded or used unsustainably. The gap between the rich and poor is also increasing - between 1990 and 2005, income inequality (measured by the gap between the highest and lowest income earners) rose in more than two thirds of countries. The persistence of poverty and degradation of the environment can be traced to a series of market and institutional failures that make the prevailing economic model far less effective than it otherwise would be when advancing sustainable development goals. These market and institutional failures are well known to economists, but little progress has been made to address them. For example, there are not sufficient mechanisms to ensure that polluters pay the full cost of their pollution. There are "missing markets" - meaning that markets do not systematically account for the inherent value of services provided by nature, like water filtration or coastal protection. A "market economy" alone cannot provide public goods, like efficient electricity grids, sanitation or public transportation. And economic policy is often shaped by those who wield power, with strong vested interests, and it rarely considers the voice and perspectives of those most at risk.

From this perspective, there are the following groups of preconditions:

- For many centuries mankind adhere to the "philosophy of consumption". The environment was used as a source of resources which was needed to meet growing demand of goods.

- Resource-destroying technologies dominated and were fed by illusion of an inexhaustible resource potential.

- $\quad$ Resource prices do not reflect their true value, that is why the depletion of the resource potential and environmental degradation occurred.
- $\quad$ Existence of groups of countries with different levels of development.

Thereby, main problems can be defined as an extended process of deformation during usage of the current technological development in connection with the great threat of pollution of the planet. Moreover, it can be defined as an inability to meet the needs of the present without compromising the ability of future generations to meet their own needs [19].

\section{MODEL AND RESUltS ANALYSIS}

In just a short time, the resource needs of this generation have changed dramatically. All that is said above ties together concern for the carrying capacity of natural systems with the social, political, and economic challenges, faced by humanity. With the growth of both population and prosperity, especially in developing countries, the prospect of much higher resource consumption levels is "far beyond what is likely sustainable" if realized at all given there are finite world resources, the report warns [20]. However, the current rate of resource use by developed and developing nations is unsustainable, meaning that future generations and developing nations will not have access to their fair share of scarce resource [21].

If one continues a "business as usual" approach to meet the rising global demand for food, energy and infrastructure, the world will exceed its ecological carrying capacity. Economic growth may be associated with a change in the composition of economic output or in the techniques that are used in production. In particular, to take advantage of many new technologies [22], firms need business models that function at the intersection of various, global industries. Such innovative business models can emerge only when the regulatory framework and relevant politics support their development [23]. For other pollutants, there is an inverted-u shaped relationship with output. Finally, for some types of pollution, there is no evidence at all that a turning point has yet been reached [24]. Industrial ecology cannot always be counted upon to yield competitive advantage at the firm level. In some cases, the cost of closing loops will exceed the benefits. In other cases, regulatory requirements do not fully internalize environmental costs, and thus polluting firms may gain temporary or permanent cost advantages relative to companies that attempt to eliminate all emissions [25].

While environmental investments are welcomed by society, managers need to identify the circumstances favoring the generation of both public benefits and corporate profits. For some firms, better utilization of resources may pay-off as environment-related investments. For others, having some eco-labeled products can eventually be the best way of pursuing competitive advantage. The urge to modernize is a compulsion inherent in capitalistic market economies, and the increasing competition for innovation in industrialized countries has led to the continuous acceleration of technological modernization [26].

As the authors suppose, there are three types of business stimulation: from local or global market, governmental and mixed stimulation. What is notable, the usage of a stimulation strategy depends on the development level of country's 
economy. For instance, in China, the environmental stimulation strategy is formulated by central government and implemented by local government [27].

In the United States, policy makers are not only concerned with job creations, but also overall fiscal health of the government, partially affected by the tax revenues [28]. Thus, growth of ecological enterprises is stimulated by government. Let us assume that nowadays it is the most effective way to increase the role of environmental entrepreneurships of developed countries and in countries with emerging economies. Although, several European highly-developed countries do have such social system, in which competitive powers of market allows ecological enterprises to gain higher profits. Looking ahead, innovation through eco-focused marketing can be a key differentiator for companies, looking to succeed in emerging markets [29].

Developing countries have the greatest opportunities for capitalizing on the synergies between environmental and economic sustainability. A green growth approach is the chance for emerging and developing economies to leapfrog unsustainable and wasteful production and consumption patterns. They can still factor environmental issues into their infrastructure investment decisions and can further develop agriculture and other natural resources in a way that improves livelihoods, creates jobs, and reduces poverty. They are less constrained than developed countries, who are now locked into investment choices and sunk capital from previous decades. Adequate financing and capacity would offer developing economies the opportunity to lay down the infrastructure and networks, needed to support environmental business [30].

The realization of the economic modernization of Russia should take into account the enormous possibilities of the country in terms of providing ecosystem services, including the role of the global ecosystem of forests, wetlands and other natural ecosystems. This will allow one to position Russia not only as an energy state, but also as an ecological donor, which involves the capitalization, receiving benefits by the country from its ecosystems [31].

What is more, it is very important to create a compliance supervising system. In the case of enterprises, it should be the state governments; in the case of countries, it should be international organizations, which are created when certain incentives and supporting proposals appear concerning the adoption of rules by all elements of the system.

Martin Janicke states in his article that there is an evidence for growing importance of regulation in the environmental sphere; he also stresses the fact that ecological regulation is a political concept and it should come from government in the first place [32]. The authors share the opinion, but in case of environmental entrepreneurship, there are several peculiarities.

It is vital to point out that in the model, the following things must be specified:

- parts of the system (e.g. state economy, local government, enterprise );

- $\quad$ way of communication between parts of the system;
- initiative ties inside the system.

The initiative of the state has some benefits, but the company already owns its strategy on organizing competitive conditions in the market [33]. On the contrary the state creates laws and forces companies to obey them. From time to time, even companies can address the state authorities and ask to create certain conditions, so they will be able to implement green technologies ambitions without serious loss [34]

The model which is realized in the U.S. operates with help of a group of enterprises. Particularly, the government creates the conditions for ecological entrepreneurships by adopting laws and establishing taxes or fee [35]. Then companies continue to work on the basis of global market and the system of demand-supply without an intervention from the state [36]. This model can be named as a "model of free market regulation" - strategy A.

In order to deliver on the new growth target, the government of Japan is promising an increased focus on fastgrowth sectors, including renewable energy, green vehicles, farming and healthcare. Although, governmental regulation of green economy market is strict, there is a high level of corporate culture among Japanese enterprises, especially on international markets. In addition, companies create conditions for development of this economic sector with the support of the government. Thus, this model can be named as a "mixed regulatory model". It is important to consider the level of development of entrepreneurship in the economy. [37,38].

One of the most interesting fact is that the Chinese model has a strong policy framework in place to transit to a green economy, but significant challenges stand in the way. They include its pollution problems and the technology gap between Chinese firms and their international competitors, according to a study, sponsored by the United Nations Environment Program [39] and the Chinese Ministry of Environmental Protection. For China, it would be beneficial to increase its investment in research and development to tackle the country's environmental challenges and to help its green industries compete globally. Therefore, the model can be named as a "model of governmental regulation". Table 1 shows their specifications.

TABLE I. THE MODEL OF THE PUBLIC-PRIVATE PARTNERSHIPS

\begin{tabular}{|c|c|c|c|}
\hline \multirow{2}{*}{ Regulating force } & \multicolumn{3}{|c|}{ Actors } \\
\cline { 2 - 4 } & Business & Partnership & Government \\
\hline "Market regulation" & $\begin{array}{c}\text { Strategy } \\
\text { A }\end{array}$ & $\begin{array}{c}\text { Interim } \\
\text { strategy }\end{array}$ & $\begin{array}{c}\text { Interim } \\
\text { strategy }\end{array}$ \\
\hline $\begin{array}{c}\text { Government } \\
\text { incentives and } \\
\text { programs }\end{array}$ & $\begin{array}{c}\text { Interim } \\
\text { strategy }\end{array}$ & Strategy B & $\begin{array}{c}\text { Interim } \\
\text { strategy }\end{array}$ \\
\hline State control & $\begin{array}{c}\text { Interim } \\
\text { strategy }\end{array}$ & $\begin{array}{c}\text { Interim } \\
\text { strategy }\end{array}$ & Strategy C \\
\hline
\end{tabular}

Government can help business to use resources more efficiently and manage their environment impact by:

- $\quad$ funding the body, which gives advice and support to help businesses use raw materials, water and energy more efficiently; 
- funding the body, which accredits other organizations' environmental award schemes, to make sure these have high standards;

- $\quad$ supporting innovations that make products and services more environmentally friendly;

- helping companies to see waste as a resource and divert it away from landfill, encouraging reuse and recycling;

Though, while modeling, initiatives can come from companies, which are concerned about environment, or companies, which can predict the green products of high demand for population.

In both cases, driven power is different and dependant on economic prosperity of the country.

On the basis of the mentioned-above models, emerging economies should at first stick to the "model of governmental regulation" in order to create the space for ecological enterprises and also in order to make these companies able to compete in conditions of free market. The government should support business to innovate and to reduce environmental impacts of products and supply chains, providing funding through a number of competitions, such as supply chain innovation towards a circular economy. Also, a scheme that aims to increase investor confidence in new innovative technologies should be provided through third party verification of performance. Then the country can change the model for "free market regulation" and let the enterprises drive their growth by themselves. But actually, the authors believe that "mixed model" is the most suitable for emerging countries in contemporary world because it combines two other models and have both beneficial aspects.

Russia, like the whole world, is facing new challenges nowadays [40]. They determine the need to modernize the economy, including innovative development and energy efficiency. One should not forget that nature and the modernization are determined by its ultimate goal, which, despite the importance of economic growth, technical excellence and competitiveness is to improve the lives of everyone today and to provide enabling environment for future generations. Efficient and timely measures to ensure environmentally sound production are to establish a widespread system of voluntary certification of corporate social accountability, including reporting on sustainable development, based on the growing demand for environmental goods and services in the world and domestic markets. In Russia, management of environmental entrepreneurship is part of government's social and economic policies and a set of legal, economic, social, organizational, informational, consulting and other measures, implemented by public authorities at all levels to ensure the implementation of a favorable environment for its development.

Ecological entrepreneurship could save Russia from the environmental disaster in future. According to the Ministry of Natural Resources, Russia dump about 1.4 billion tons of various types of wastes. Moreover, 89.8 million tons of hazardous and toxic products are added to that volume every year. Primarily, they are oil and its products. The condition of natural environment is in "national security interests of the country". About $15 \%$ of the countries territory is considered a "zone of ecological catastrophe." About half the population drinks water that does not meet sanitary standards. About twothirds of the population is forced to live in areas where air pollution exceeds the acceptable level. Cause of the unfortunate situation is seen in lack of effective mechanisms for monitoring environmental problems; government should pay attention to the unpreparedness of the economic conditions that could have encouraged conservation of nature. Also, there is disengagement of the state from the conversation process with environmental businesses. There is no economic base that would solve current environmental problems.

There is a need for creation of environmental businesses, which could provide "uniformly produced environmental products, their conformity to standards, licensing companies, the introduction of advanced technologies." Greening the economy cannot be achieved without the participation of the state. That is why Russia should adopt the "model of governmental regulation" in order to enhance competitiveness of ecological enterprises which will improve environmental situation all over the Russian Federation.

\section{ASSET MANAGEMANT}

Application of the classical strategy of management of assets with high dynamics of conditions of the enterprise environment is problematic, as it tends to have the linear model of an assessment of situation development. During the usage of such models, deformations are often found out after the realization of its negative effect. One can observe not deformation, but its negative effect, and the company cannot manage it any more. The company cannot use potentially favorable offers in time, because there is the high changing speed of the external environment. "Good working capital management acts as a hedge against tightening credit and reduced access to external capital" [31].

\section{Hypothesis 1}

The inefficiency of using the classical strategy of forming and financing assets, in view of an increase in frequency of changes of environment, causes a need of the development of multicriteria model. Earlier, the organization could successfully function and choose between two classical strategies - maximizing liquidity at a certain level of profitability or maximizing profitability at a certain level of liquidity. It was available because the frequency of changes of external environment was rather low, and companies could plan the course of events and use one of the offered strategies for a certain period. Nowadays the environment changes very quickly, so the companies need to have opportunity to change the structure of the assets and liabilities quickly.

\section{Hypothesis 2}

The model must stabilize independently, adapt automatically to the changes of external conditions, or at least, give the company a chance to find the deformation and to eliminate it before the negative effect approaches.

Hypothesis 3 
The multicriteria model must provide a possibility of constant readiness for potential opportunities; on the one hand, the most part of assets must be involved in the current activity, and, on the other hand, the company has to accumulate a large volume of financial resources for making potentially good transactions in the shortest time.

In the conditions of instability, there is a need of creation of a non-linear structure and sources of the assets management strategy which differs from the existing one by ability of autonomous self-regulation of target orientation (on profitability or on liquidity) in time.

Nowadays, the companies have the limited access to credit resources because of the low trust from financial institutions. Possibility of using the overdraft eliminates the need of existence of liquidity reserve in the bank. Using the overdraft is favorable by several positions. Firstly, the company has an opportunity to fulfill their liabilities to contractors in time and in full volume. Secondly, the released resources can be profitably invested. Finally, if the number of turns of the company grows, the limit of an overdraft grows as well. At the high level of trust, the bank can increase an overdraft limit. It is also smart to use insurance of the contractor's responsibility instead of creating a large number of reserves.

Using the repo operations, the company can increase shortterm liquidity, make balance free of undesirable assets for a certain period and multiply the capital in the financial market. The purpose of the transaction is temporary granting financial resources under an ownership right concession on property, or ' "pledge' of property. The main condition of using the repo scheme in the conditions of constantly changing environment is an existence of the organizations, which are ready to buy fixed assets of the company with the right of repurchase.

Important sources of financing of material resources updating are, for example, the accelerated depreciation of fixed assets and leasing. While using the leasing, the risk of the equipment obsolescence entirely lays down on the lessor, and the lessee has a possibility of continuous update of the equipment park. Devos and Rahman (2014) mentioned that leasing is comparable in importance to long-term debt [32].

One more way to receive cheap financial resources is an association with other companies. Such association acting like 'a uniform asset' (the cross guarantee) has good chances to receive the credit on profitable terms. The level of development of business relations is also an important factor in this context [33, 34, 35].

For the effective use of multicriteria model, it is important to use a synergy of two directions. For example, if the profitability and profit of the company is higher, the bank is ready to give a larger sum of overdraft and the crediting rate on a repo or leasing is lower.

Using the mechanism of preliminary arrangements, the company has to be able not to miss potentially favorable offers. In a case when the company involves all resources (maximization of profitability and minimization of liquidity), but it has an arrangement with bank about overdraft and with the company about repayment in a report of fixed assets, the company does not need to take a loan from the bank when the potentially good transactions appear. The company can mobilize a large volume of financial resources at the reasonable price for the short period $[36,37,38]$.

Inefficiency of using the existing strategies of forming and financing the assets with the increase of frequency of external environment changes was the background to develop the multicriteria model. The main feature of the model is that the company has two directions (liquidity and profitability), which, on the one hand, are not maximized, and, on the other hand, there is a possibility of automatic maximizing one of the directions at every period. The model has an ability of autonomous self-regulation of the target orientation (on profitability or on liquidity) in time with using the mechanisms of overdraft, insurance of responsibility of suppliers, transactions on the repo type, and leasing as well. For the public company, investors can use also market data $[39,40,41]$

Further, it is necessary to carry out the empirical research of this model, pass from the theory to the practice and to formulate more particular methods of its realization [42].

\section{CONCLUSIONS}

Our study has shown that the development of ecological entrepreneurship in the first place is a concern of the government. Therefore, it is hard for eco-company to be competitive in conditions of free market on a local and especially on global scale. The national political and socioeconomic environment strongly determines how companies use in practice ecological technologies.

What is more, the authors defined three models of relations between state authorities and enterprises, the levels of subordination, the means of development in environmental sphere of economy:

- model of free market regulation;

- model of governmental regulation;

- $\quad$ mixed regulatory model.

Applying the research to economic situation in the Russian Federation, let us assume that ecological business needs the support for the modernization of production by means of a socalled win-win situation, associated with the provision of both economic efficiency and a reduction of harmful emissions, sustainable use of natural resources and low waste production.

It is necessary to ensure the safe use of traditional resources and energy efficiency. Implementation of the multiple opportunities for improving energy efficiency involves the introduction of urgent measures to ensure the interest in energy conservation at all levels - from the industrial development to a household. And in such situation, ecological entrepreneurship is the best choice to recall to.

\section{References}

[1] R. Isaak, Globalization and green entrepreneurship. Green Management International, 18, pp. 80-90, 1997. 
[2] L.U. Hendrickson, D.B. Tuttle, Dynamic management of the environmental enterprise: a qualitative analysis. Journal of Organizational Change Management, 10, pp. 363-382, 1997.

[3] Working towards a Balanced and Inclusive Green Economy: a UN system-wide perspective, United Nations, 2011.

[4] Lin, H., S.X. Zeng, Can political capital drive corporate green innovation? Lessons from China, Journal of Cleaner Production, 64, pp. 63-68, 2013.

[5] Karapetrovic, S., M. Casadesús, Implementing environmental with other standardized management systems: scope, sequence, time and integration. J. Cleaner Prod,17, pp. 533-540, 2009.

[6] W-M. Cheng, Renewable energy in eastern Asia: Renewable energy policy review and comparative SWOT analysis for promoting renewable energy in Japan, South Korea, and Taiwan, Energy Policy, 74, pp. 319325, 2014.

[7] United Nations Environment Programme (UNEP), Global green new deal: policy brief. Geneva, Switzerland: UNEP, pp. 150-152, 2009.

[8] T. Dean, J. McMullen, Toward a theory of sustainable entrepreneurship: reducing environmental degradation through entrepreneurial action. Journal of Business Venturing, 22(1), pp. 50-76, 2007.

[9] R. Gouvea, S. Kassicieh, Using the quadruple helix to design strategies for the green economy, Technological Forecasting and Social Change, 80( 2), pp. 221-230, 2012.

[10] B. Cohen, M.I. Winn, Market imperfections, opportunity and sustainable entrepreneurship. Journal of Business Venturing, 22 (1), pp. 30-32, 2007.

[11] V. Smirnov, Scientific approaches to understanding business. Theory and practice of social development, 2, pp. 272-274, 2012.

[12] E. Gafforova, N. Merkushova, V. Smirnov, V. Batalova, Y. Merkushova, Using Crowdsourcing to Expand the Resource Base of Business. Asian Social Science, 11(7), pp. 91-97, 2015.

[13] V. Smirnov, Using scientific reflection in the study of entrepreneurship. Life Science Journal, 11(9s), pp. 303-306, 2014.

[14] J. Betz, B. Never, Comparing the Climate Policy Performance of Emerging Economies, World Development, 59, pp. 1-15, 2014.

[15] G. Glomma, D. Kawaguchi. Green taxes and double dividends in a dynamic economy, Journal of Policy Modeling, 30, pp. 19-22, 2007.

[16] J. Zhang, Promoting green ICT in China: A framework based on innovation system approaches, Telecommunications Policy, 39 (10-11), pp. 997-999, 2012.

[17] D.H. Lee, Development and environmental impact of hydrogen supply chain in Japan, pp. 30-35, 2014.

[18] S.E. Kim, H. Kim, A new approach to measuring green growth: Application to the OECD and Korea, Futures, 63, pp. 37-48, 2014.

[19] Brundtland Commission 1987. "Report of the World Commission on Environment and Development", pp: 258-260.

[20] Humanity's voracious consumption of natural resources unsustainable United Nations report. Date Views 01.11.2014 www.un.org/apps/news/story.asp?NewsID=38366\#.VHnzB8m0SSo/.

[21] Schandl, H., Sustainable use of natural resources, Electronic source Date Views 01.11.2014 www.csiro.au/Outcomes/Energy/CarbonFootprint/Sustainable-Resource-Use.aspx/.

[22] N.A. Ashford, C. Ayers, Stone RF. Using regulation to change the market for innovation. Harvard Environmental Law Review, 9(2), pp. 812, 1995.

[23] M. Richter, Business model innovation for sustainable energy: German, Energy Policy, 62, pp. 1226-1230, 2013.

[24] G. Grossman, Pollution and Growth: What Do We Know? Date Views 01.11.2014 www.ideas.repec.org/p/cpr/ceprdp/848.html\#author/.

[25] E.M. Porter, D.C. Esty, Industrial Ecology and Competitiveness, Yale Law School Scholarship Repository, pp. 36-37, 1998.

[26] M.C. Cuerva, Drivers of green and non-green innovation: empirical evidence in Low-Tech SMEs. Journal of Cleaner Production, 68, pp. 104-110, 2014.

[27] P. Feng, Environmental regulation strategy analysis of local government based on evolutionary game theory. Management Science \&
Engineering (ICMSE), 2014 International Conference, pp:1957-1964, 2014.

[28] C. Chamley, Optimal taxation of capital income in general equilibrium with infinite lives. Econometrica, 54(3), pp. 607-622, 1986.

[29] T. Kenyon, Shades of Green - emerging markets go eco. Date Views 01.11.2014 www.gfk.com/magazine/talk/hitting-the-target-innovatingfor-rising-target-groups/50-shades-of-green-emerging-markets-go-eco/.

[30] Bansal, P. and K. Roth, 2000. Why companies go green: a model of ecological responsiveness. Academy of Management Journal, 43 (4): 717-719.

[31] Centre for Environment Policy of Russia, Towards green economy in Russia (review), Moscow, 2012. Date Views 01.11.2014 www.sustainabledevelopment.ru/upload/File/Reports/ISD_UNEP_GE_ Eng.pdf/.

[32] M. Janicke, Ecological modernisation: new perspectives, Journal of Cleaner Production, 16(5), pp. 557-561, 2008.

[33] P. Berrone, L. Gomez-Mejia, Environmental performance and executive compensation: an integrated agency institutional perspective. Academy of Management Journal, 52 (1), pp. 103-109, 2009.

[34] W.R. Meek, The impact of social norms on entrepreneurial action: Evidence from the environmental entrepreneurship context, Journal of Business Venturing, 25(5), pp. 493-506, 2010.

[35] Vazquez-Brust, D., 2014. Managing the transition to critical green growth: The 'Green Growth State', Futures, 64: 38-40.

[36] Hongtao, Y., Green businesses in a clean energy economy: Analyzing drivers of green business growth in U.S, Energy, 68: 922-929.

[37] V. Smirnov, The theoretical basis of modern researching entrepreneurship. Modern Competition, 1 (49), pp. 58-74, 2015.

[38] V. Smirnov, B. Belkin, Experience in the Application of the Principle of Methodological Pluralism in the Study of Entrepreneurship. Asian Social Science, 11(7), pp. 122-127, 2015.

[39] China's green long march, UNEP, 2012. Date Views 01.11.2014 www.unep.org/greeneconomy/Portals/88/Research\%20Products/China\% 20synthesis\%20report_FINAL_low\%20res_22nov.pdf/.

[40] N.P. Tarasova, The development of Green Chemistry in Russia as a tool to improve the competitiveness of chemical products, Journal of Cleaner Production, 83, pp. 491-496, 2014.

[41] A. Nagapetyan, E. Rubinshtein," Comparison of positive and negative risk indices as a tool for portfolio management," Actual Problems of Economics, vol 7, pp. 142-150, 2016.

[42] L. Wang, A. Nagapetyan, E. Lutsenko and V. Pakhmutov, "Theory and methodology for financial infrastructure of foreign direct investment in developing countries: The BRICS case," International Review of Management and Marketing, vol 6(S1), pp. 179-183, 2016. 